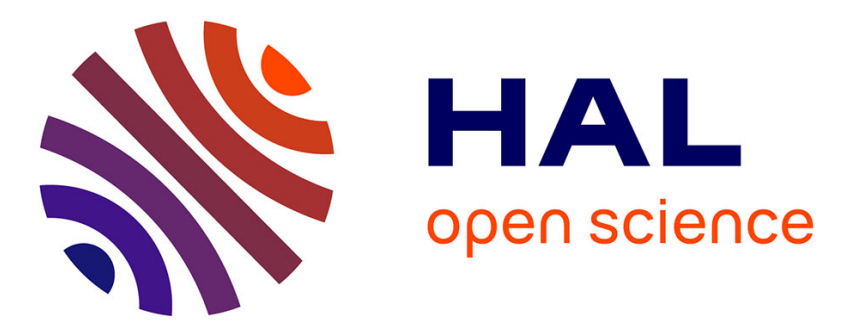

\title{
Intraspecific sex-pheromone variability in the European corn borer, Ostrinia nubilalis Hbn. (Lepidoptera, Pyralidae)
}

Pierre Anglade, Jacques Stockel, I.W.G.O. Cooperators

\section{- To cite this version:}

Pierre Anglade, Jacques Stockel, I.W.G.O. Cooperators. Intraspecific sex-pheromone variability in the European corn borer, Ostrinia nubilalis Hbn. (Lepidoptera, Pyralidae). Agronomie, 1984, 4 (2), pp.183-187. hal-00884625

\section{HAL Id: hal-00884625 \\ https://hal.science/hal-00884625}

Submitted on 1 Jan 1984

HAL is a multi-disciplinary open access archive for the deposit and dissemination of scientific research documents, whether they are published or not. The documents may come from teaching and research institutions in France or abroad, or from public or private research centers.
L'archive ouverte pluridisciplinaire HAL, est destinée au dépôt et à la diffusion de documents scientifiques de niveau recherche, publiés ou non, émanant des établissements d'enseignement et de recherche français ou étrangers, des laboratoires publics ou privés. 


\title{
Intraspecific sex-pheromone variability in the European corn borer, Ostrinia nubilalis Hbn. (Lepidoptera, Pyrali- dae)
}

\author{
Pierre ANGLADE, Jacques STOCKEL \& I.W.G.O. COOPERATORS (') \\ I.N.R.A., Station de Zoologie, Centre de Recherches de Bordeaux, F33140 Pont-de-la-Maye
}

Following the first survey of intraspecific pheromone variability in Ostrinia nubilalis Hbn (ECB) in Europe and North America (KLUN \& COOPERATORS, 1975), the sex attraction responses of male populations of ECB to 3 ratios of the $Z: E$ isomers $(97: 3,35: 65,3: 97)$ of the 11-tetradecenyl acetate were studied at 28 locations in Europe, 3 in Egypt and one in the Hebei province of the People's Republic of China, during the 1978-1981 period, as a part of the cooperative program of I.W.G.O. (International Working Group on Ostrinia). In the palearctic region, the ECB populations exhibited pheromone polymorphism. The $\mathrm{Z}$ phenotype was the only one observed in 13 localities, mainly with low levels of capture. In other places, the two phenotypes $Z$ and $E$ were in sympatry, very often with the presence of their presumed hybrid $Z \times E$, responding to the $35: 65 \quad Z: E$ mixture. The survey confirms the great prevalence of the $Z$ phenotype in corn fields all over the world. The E phenotype was prevalent only in 5 locations in northern Italy and southern Switzerland.

Additional key words : Polymorphism, 11-tetradecenyl acetate, China, Egypt, Europe.

Après une première enquête sur la variabilité phéromonale intraspécifique de la pyrale du maïs, Ostrinia nubilalis Hbn., en Europe et en Amérique du Nord (KLUN \& CoOPERATORs, 1975), les réponses des populations de mâles de pyrale à l'attraction sexuelle de 3 mélanges des isomères $Z$ et $E$ du 11-tétradécényl acétate dans les proportions $Z / E$ 97/3, 35/65, 3/97, ont été étudiées en 28 lieux d'Europe, 3 en Egypte et un dans la province d'Hebei en République populaire de Chine, durant la période 1978-1981 en tant que partie du programme coopératif de l'I.W.G.O. (Groupe de travail international sur Ostrinia). Dans la région paléarctique, les populations de pyrale manifestent un polymorphisme pour leur phéromone sexuelle. Si le phénotype $Z$ est le seul observé en 13 lieux, caractérisés en général par de faibles captures, dans les autres lieux, les 2 phénotypes $Z$ et $E$ sont sympatriques, très souvent avec la présence de leur hybride présumé $\mathrm{Z} \times \mathrm{E}$ répondant au mélange $\mathrm{Z} / \mathrm{E} \quad 35 / 65$. L'enquête confirme la grande prédominance du phénotype $\mathrm{Z}$ dans les cultures de mais dans le monde entier. Le phénotype $E$ n'est prédominant que dans 5 localités du Nord de l'Italie et du Sud de la Suisse.

Mots clés additionnels : Polymorphisme, 11-tétradécényl acétate, Chine, Egypte, Europe.

\section{(1) I.W.G.O. COOPERATORS :}

W. AWADAllaH
F. BACA
H. BERGER
F. BISCHOF
R. BUCHI
S. CAVICCHI
F. COPPOLINO
L. GERGINOY
CZ. KANIA
S. MAINI
D. MUSTEA
M. MYSLICKY
B. NAGY
B. OHNESORGE
G. ROTUNDO
D. ZHOU

Plant Protection Research Institute, Cairo, Egypt. Institut za kukuruz, Zemun, Yugoslavia.

Bundesanstalt für Pflanzenschutz, Wien, Austria

Regierungspräsidium, Karlsruhe, Federal Republic of Germany.

Eidg. Forsch. Landw. Pflanzenbau, Zurich-Reckenholz, Switzerland.

Universita degli studi, Bologna, Italy.

Istituto Cerealicoltura, Bergamo, Italy.

Maize Research Institute, Kneja, Bulgaria.

WSR College Agriculture, Wroclaw, Poland.

Universita degli studi, Bologna, Italy.

Academia de Stinte agricole, Turda, Romania.

WSR College Agriculture, Wroclaw, Poland.

Novenyvedelmi Kutato Intezet, Budapest, Hungary.

Universität Hohenheim, Stuttgart, Federal Republic of Germany.

Universita degli studi, Portici, Napoli, Italy.

Institute of Plant Protection, Chinese Ac. Agric. Sci., Beijing, People's Republic of China. 


\section{INTRODUCTION}

The sex pheromone communication system of the European Corn Borer (ECB), Ostrinia nubilalis Hbn., is dependent on the balance of the $\mathrm{Z}$ and $\mathrm{E}$ geometric isomers of the major component of the pheromone, the 11-tetradecenyl acetate (11-tda) (KLUN et al., 1973). In the United States, where the species was introduced seventy ycars ago, the males of the Corn Belt respond to the mixture of Z-11-tda with traces of E isomer (KLUN \& ROBINSON, 1971), but the males of the Northeastern States respond to the opposite blend, a mixture of E-11-tda with traces of the $\mathrm{Z}$ isomer (RoElOFs et ai., 1972). In these 2 areas, the isomeric compositions of the natural pheromone of the females was found to be respectivcly $97: 3 \mathrm{Z}: \mathrm{E}$ and $4: 96 \mathrm{Z}: \mathrm{E}$ (KOCHANSKY et al., 1975). In France, first surveys (ANGLADE, 1974) have shown that males respond almost exclusively to the $97: 3 \mathrm{Z}:$ E mixture. In a 2-year survey in North America and Europe, KLUN \& COOPERATORS (1975), using 5 isomer formulations in 31 locations, have found that in most cases males were attracted to the $97: 3$ $\mathrm{Z}: \mathrm{E}$ blend and responded preferentially to the $3: 97$ $\mathrm{Z}$ : $\mathrm{E}$ blend in only 3 locations, in Italy and in the NorthEastern States (New York and Pennsylvania); they also found that in areas where the 2 types $Z$ and $E$ are in sympatry (Austria, Central France, New Jersey, Pennsylvania), a significant number of males were attracted to the $1: 1$ mixture and they hypothesized that these males were hybrids between the 2 types.

Genetic studies in the laboratory (KLUN \& MAINI, 1979) demonstrated that the geometric composition of the female ECB sex pheromone is controlled by simple mendelian inheritance involving a single pair of alleles with incomplete dominance. The female $A A$ secretes a mixture approximately $3: 97 \mathrm{Z}: \mathrm{E}$, the aa one approximately $97: 3 \mathrm{Z}: \mathrm{E}$ and the hybrids $A a$ an isomer mixture of about $35: 65$ $\mathrm{Z}: \mathrm{E}$. The males seem to respond more intensely to the isomer ratio secreted by sibling females and male hybrids especially respond preferentially to the $35: 65 \mathrm{Z}: \mathrm{E}$ isomer combination. However, each male type may also respond to all isomer blends, in different proportions.

The three different forms were detected in feral populations in New Jersey and Italy, showing that opposite forms hybridize in nature, as a result of aggregation by environmental stimuli (SHOWERS et al., 1976) and that they serve as a bridge for gene flow between their parent genotypes (KLUN \& MAINI, 1979). Based on the wide distribution of the $\mathrm{Z}$ form and the presence of the $\mathrm{E}$ form in a small number of more restricted areas, the hypothesis was made that the large scale cultivation of corn might exert selection pressure in favour of the $Z$ form (ANGLADE, 1977).

We report here the results obtained by the members of the International Working Group on Ostrinia (I.W.G.O.) for 4 years (1978, 1979, 1981 and 1982) mainly in Europe, but also in Egypt and in the People's Republic of China (1981) during a survey of sex attraction response specificities of populations of ECB males. This study was scheduled in order to enlarge the field of the 1973-74 survey (KLUN \& COOPERATORS, 1975), and to verify the stability of its results, especially in the areas where the ECB cxhibits pheromone polymorphism. Additional results from China and Switzerland are also included in the present paper, with the permission of the authors.

\section{MATERIALS AND METHODS}

For the I.W.G.O. program, the insect traps and chemicals were generally supplied by the "I.N.R.A. Station de Zoologie, Bordeaux". The traps were straight prism cartons "I.N.R.A." design (STOCKEL, 1977) with a sticky sheet on the bottom (STOCKEL, 1981b).

The chemicals ( $\mathrm{Z}$ and $\mathrm{E}$ isomers of 11-tda) were synthesized by the "I.N.R.A. Médiateurs chimiques" Laboratory at Brovessy. The stereochemically pure isomers were used to prepare formulations of 11-tda in hexane solution with 3 ratios $Z: E \quad 97: 3,3: 97$ and $35: 65$. The last of these has been demonstrated as the pheromone component of the hybrid $\mathrm{Z} \times \mathrm{E}$.

Rubber septa (Ets LEUNE, Orsay, France) were treated by topical application with each blend. We used $100 \mu \mathrm{g} 11$ tda for one septum which was demonstrated to be the best amount of pheromone bait for $O$. nubilalis (STOCKEL, $1981 a$ ) with an addition of $1000 \mu \mathrm{g}$ tetradecyl acetate which has a synergic effect on male captures (STOCKEL, 1980). The rubber septa were prepared just before they were mailed to the participants, who placed them after receipt into cold storage until they were deployed in the fields.

In each of the 4 years, sex-trapping material was mailed to each of the 12 participating countries. The number of sex trapping locations was fixed each year by each cooperator depending upon the local situation (fig. 1). Each scx trapping location involved 3 traps with 3 lots of rubber plugs corresponding to the 3 pheromone blends.

In order to make the results of different countries comparable, some guidelines were followed: the sex traps were placed at least $50 \mathrm{~m}$ from each other at the perimeter of the cornfield. The sex traps were positioned on stakes at a level with the growing host plants. The insects were counted twice a week for about 2 months. Changes of bait were made cvery two weeks and the sticky sheets were replaced when necessary (about once every 3 weeks).

In Bologna, Italy, during the second ECB flight, in 1979 and 1980 , virgin female traps were set up with females obtained from laboratory rearing (MAINI et al., 1978) of the two strains Iowa $(\mathrm{Z})$, New York (E) and the F $1 \mathrm{E} \times \mathrm{Z}$.

\section{RESULTS}

The results of the study are summarized in table 1. During the 4 years, results were obtained from 32 different locations in 12 countrics in Europe, Near East (Egypt) and Far East (the Hebei province, China) (fig. 1).

On 26 occasions out of the 49 place and year combinations, the 2 phenotypes $Z$ and $E$ were in sympatry. Very often (23/26), the males also responded to the $35: 65$ $\mathrm{Z}: \mathrm{E}$ mixture, as $\mathrm{Z} \times \mathrm{E}$ hybrids. In the other cases, homogeneous responsiveness to the $97: 3 \mathrm{Z}: \mathrm{E}$ 11-tda was observed, mainly in places and years which gave low levels of captures, the three localities in Egypt and one in Germany excepted.

The $Z$ phenotype, responding to the $97: 3 \quad Z: E$ 11-tda, was prevalent everywhere, except in 5 localities in Europe where the $E$ phenotype, responding to the $3: 97 \quad \mathrm{Z}: \mathrm{E}$ was prevalent : Bergamo, Bologna, Pistoia (Italy), Berganzona and Gordola (Switzerland).

The percentages of captures of males responding to the $35: 65 \mathrm{Z}:$ E seemed to be higher in the places where the E phenotype was prevalent (Bologna, from 31 to $61 \%$, Pistoia $29 \%$, Berganzona 22 and $20 \%$, Gordola $14 \%$ ) 


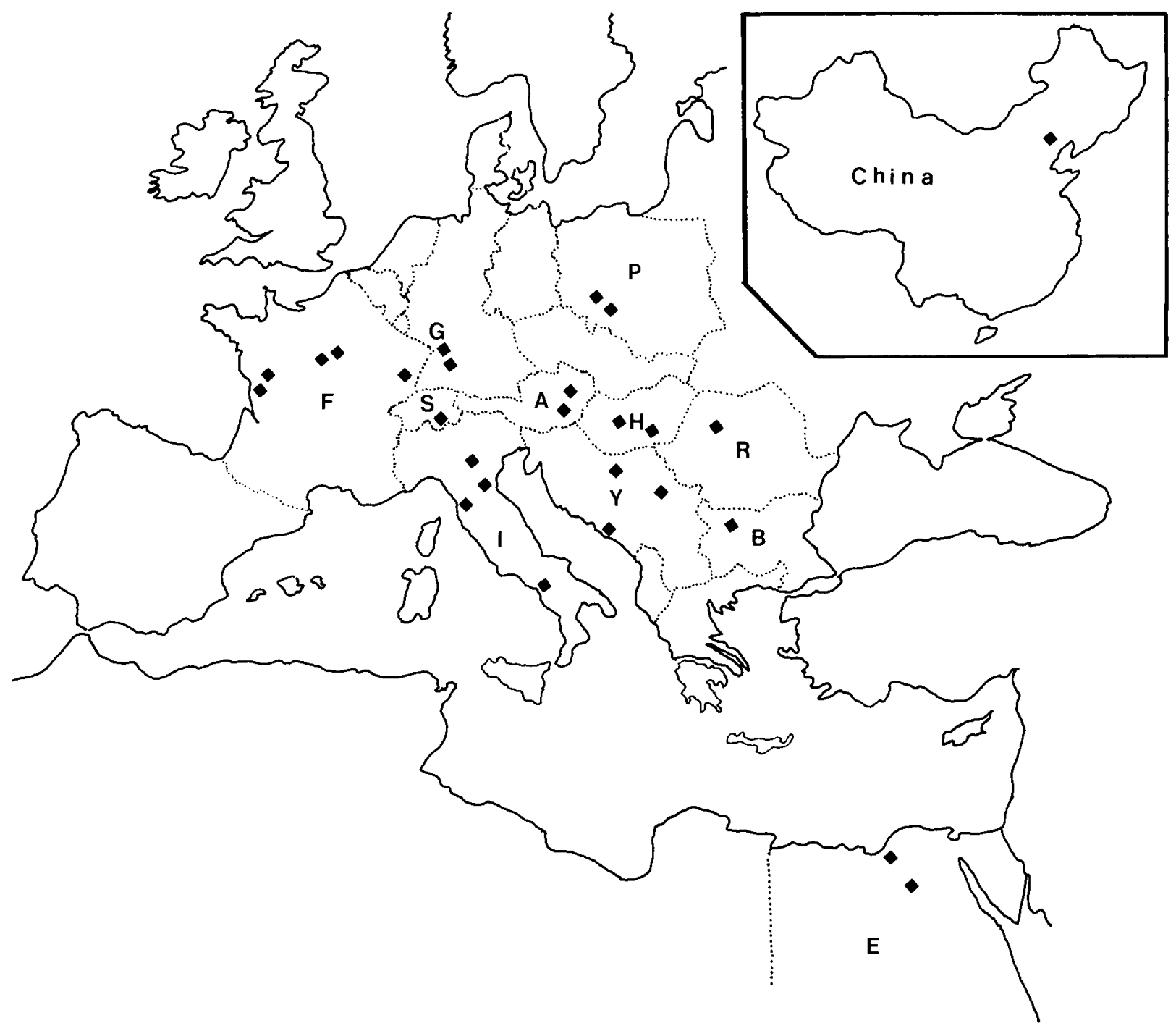

Figure 1

Distribution map of the trapping locations for ECB.

than in the opposite situations where the $\mathrm{Z}$ phenotype was prevalent (from $2 \%$ at Kneja, Bulgaria, to $13 \%$ at Levesville, France).

The percentages of males caught by virgin females of different pheromone phenotypes in Bologna were similar to those caught by the synthetic mixtures.

\section{DISCUSSION}

The present evaluation of the relative percentages of the three pheromone phenotypes $\mathrm{Z}, \mathrm{E}$ and $\mathrm{Z} \times \mathrm{E}$ in the different populations of the ECB in the participating countries might be more or less biased for 2 reasons : the males of this polyphagous species were trapped only in the vicinity of corn fields and we lack information on feral populations in areas where corn is not cultivated. Secondly, the sizes of trapped samples showed great variation, from 5 to 2084 males betwen places and years.

Nevertheless, on the basis of the two I.W.G.O. surveys in Europe, and of similar conclusions drawn from a recent trapping experiment at 15 locations in 11 provinces of the P.R. of China (W.C.C.B.R.G. et al., 1982), it seems established, in answer to the question "ECB : pheromone polymorphism or sibling species ?" (CARDÉ et al., 1978),
Carte de la distribution des lieux de piégeage de la pyrale du maïs.

that the ECB populations of the palearctic area exhibit pheromone polymorphism. The apparently pure $\mathrm{Z}$ population observed may be generally related to low levels of capture where the chances of trapping the rare phenotypes are very low.

The presence of $\mathrm{Z} \times \mathrm{E}$ hybrids was detected on many occasions, with higher percentages in Italy and Switzerland where the ratios of the 2 parental phenotypes were better balanced $(Z: E 1: 4)$ than in other places where $Z$ is prevalent $(E: Z \quad 1: 10)$. With such a balanced $Z: E$ ratio, the chances of mating between the 2 parental phenotypes were greater, giving higher frequencies of hybrids $(\mathrm{Z} \times \mathrm{E}: 0.23 / 0.05)$. The observed frequencies of hybrids were lower than the expected values according to a hypothesis of panmixis ( 0.38 and 0.18 respectively). The difference between observed and expected values was smaller in the Italian-Swiss area, where the E phenotype is prevalent. This leads to the hypothesis that the degree of homogamy would be lower for $\mathrm{E}$, which is in agreement with the percentages of precopulatory responses obtained for the opposite pheromone by KLUN \& MAINI (1979), for phenotype E from New York $(9 \%)$ and for phenotype $Z$ from Iowa $(3 \%)$.

The possibilitics of mating among the three phenotypes are dependent not only on the presence of suitable places of " rendez-vous" as a consequence of attraction of both sexes 
TABLEAU 1

Distribution of the captures of ECB males in sex-traps baited with the 3 different mixtures of the $Z$ and E-11-tda isomers, in 49 location-year combinations in Europe, Egypt and China, in the I.W.G.O. program 1978-1981.

Répartition des captures de mâles de la pyrale du maïs dans les pièges appâtés par les 3 différents mélanges des isomères cis (Z) et trans (E) du 11 tda, dans 49 combinaisons lieux-années en Europe, Egypte et Chine, au cours du programme I.W.G.O. 1978-1981.

\begin{tabular}{|c|c|c|c|c|c|c|c|c|}
\hline \multirow{4}{*}{$\begin{array}{l}\text { Countries } \\
\text { Austria }\end{array}$} & \multirow{4}{*}{$\begin{array}{l}\text { Locations } \\
\begin{array}{l}\text { Fuchsenbigl } \\
\text { Zelting }\end{array}\end{array}$} & \multirow{4}{*}{$\begin{array}{c}\text { Years } \\
1981 \\
1981\end{array}$} & \multirow{2}{*}{\multicolumn{2}{|c|}{ Trapping periods }} & \multirow{4}{*}{$\begin{array}{c}\begin{array}{c}\text { Trapped males } \\
\text { Total }\end{array} \\
14 \\
76\end{array}$} & \multicolumn{3}{|c|}{ Trapped males by isomer mixture in $\%$} \\
\hline & & & & & & $Z:$ E $97: 3$ & $\mathrm{Z}: \mathrm{E} \quad 35: 65$ & $\mathrm{Z}: \mathrm{E} \quad 3: 97$ \\
\hline & & & $26 / 6$ & $29 / 7$ & & 100 & 0 & 0 \\
\hline & & & $9 / 6$ & $4 / 8$ & & 84 & 9 & 7 \\
\hline Bulgaria & Kneja & 1981 & $11 / 6$ & $18 / 8$ & 42 & 98 & 2 & 0 \\
\hline China & Zhangjiakou $\left({ }^{1}\right)$ & 1980 & $1 / 8$ & $13 / 8$ & 253 & 95 & 2 & 3 \\
\hline & Zhangjiakou & 1981 & $16 / 7$ & $31 / 8$ & 33 & 88 & 9 & 3 \\
\hline Egypt & Alexandria & 1981 & $3 / 6$ & $15 / 9$ & 331 & 100 & 0 & 0 \\
\hline & Saft Khaled & 1981 & $3 / 6$ & $15 / 9$ & 146 & 100 & 0 & 0 \\
\hline & Sakha & 1981 & $3 / 6$ & $15 / 9$ & 210 & 100 & 0 & 0 \\
\hline France & Levesville & 1978 & $23 / 6$ & $18 / 8$ & 191 & 74 & 13 & 13 \\
\hline & Levesville & 1979 & $25 / 6$ & $17 / 8$ & 375 & 92 & 6 & 2 \\
\hline & Orsonville & 1979 & $25 / 6$ & $17 / 8$ & 203 & 96 & 2 & 2 \\
\hline & Vouillé & 1981 & $16 / 6$ & $4 / 9$ & 176 & 100 & 0 & 0 \\
\hline & St Laurent & 1981 & $30 / 6$ & $1 / 9$ & 38 & 55 & 8 & 37 \\
\hline & Bischwir & 1981 & $9 / 6$ & $14 / 8$ & 67 & 98 & 2 & 0 \\
\hline Germany & Bickenbach & 1981 & $16 / 6$ & $28 / 7$ & 169 & 100 & 0 & 0 \\
\hline & Karlsruhe & 1981 & $27 / 6$ & $10 / 7$ & 29 & 100 & 0 & 0 \\
\hline & Stuttgart & 1981 & $25 / 6$ & $6 / 8$ & 36 & 100 & 0 & 0 \\
\hline Hungary & Velence & 1978 & $11 / 7$ & $18 / 8$ & 20 & 90 & 0 & 10 \\
\hline & Mikepercs & 1978 & $4 / 7$ & $12 / 9$ & 64 & 100 & 0 & 0 \\
\hline & Mikepercs & 1979 & $2 / 7$ & $7 / 9$ & 32 & 100 & 0 & 0 \\
\hline & Tanakadj & 1979 & $7 / 7$ & $7 / 9$ & 18 & 94 & 0 & 6 \\
\hline & Tanakadj & 1981 & $6 / 7$ & $1 / 9$ & 37 & 100 & 0 & 0 \\
\hline & Seregelyes & 1981 & $1 / 7$ & $30 / 9$ & 30 & 100 & 0 & 0 \\
\hline Italy & Bologna & 1978 & $26 / 7$ & $30 / 8$ & 229 & 7 & 58 & 35 \\
\hline & Bologna & 1979 & $22 / 5$ & $24 / 8$ & 369 & 11 & 31 & 58 \\
\hline & Bologna $\left({ }^{2}\right)$ & 1979 & $4 / 6$ & $17 / 9$ & 2084 & 5 & 37 & 58 \\
\hline & Bologna $\left({ }^{2}\right)$ & 1980 & $21 / 8$ & $5 / 9$ & 304 & 5 & 61 & 34 \\
\hline & Bologna & 1981 & $26 / 5$ & $20 / 8$ & 569 & 10 & 45 & 45 \\
\hline & Bergamo & 1981 & $15 / 6$ & $28 / 8$ & 120 & 21 & 33 & 46 \\
\hline & Pistoia & 1981 & $2 / 7$ & $25 / 8$ & 66 & 35 & 29 & 36 \\
\hline & Salerno & 1981 & $2 / 7$ & $31 / 8$ & 97 & 92 & 4 & 4 \\
\hline Poland & Brnik & 1978 & $27 / 6$ & $7 / 8$ & 13 & 61 & 8 & 31 \\
\hline & Brnik & 1981 & $15 / 6$ & $20 / 7$ & 11 & 100 & 0 & 0 \\
\hline & Groraj & 1978 & $30 / 6$ & $10 / 8$ & 5 & 80 & 0 & 20 \\
\hline & Kobierzyce & 1978 & $23 / 6$ & $1 / 7$ & 16 & 100 & 0 & 0 \\
\hline & Kobierzyce & 1979 & $19 / 6$ & $12 / 7$ & 37 & 100 & 0 & 0 \\
\hline & Kobierzyce & 1981 & $25 / 6$ & $30 / 8$ & 8 & 100 & 0 & 0 \\
\hline & Borusowa & 1981 & $13 / 6$ & $3 / 8$ & 29 & 100 & 0 & 0 \\
\hline Romania & Turda & 1979 & $11 / 6$ & $24 / 7$ & 112 & 92 & 7 & 1 \\
\hline & Turda & 1980 & $16 / 7$ & $18 / 8$ & 152 & 100 & 0 & 0 \\
\hline & Turda & 1981 & $25 / 6$ & $20 / 8$ & 212 & 100 & 0 & 0 \\
\hline Switzerland & Berganzona $\left({ }^{3}\right)$ & 1976 & $13 / 8$ & $27 / 8$ & 36 & 6 & 22 & 72 \\
\hline & Berganzona $\left({ }^{3}\right)$ & 1977 & $5 / 8$ & $21 / 9$ & 40 & 10 & 20 & 70 \\
\hline & Gordola $\left({ }^{3}\right)$ & 1977 & $5 / 8$ & $21 / 9$ & 22 & 36 & 14 & 50 \\
\hline Yugoslavia & Zemun & 1978 & $27 / 6$ & $5 / 9$ & 43 & 93 & 0 & 7 \\
\hline & Zemun & 1979 & $7 / 6$ & $20 / 8$ & 87 & 85 & 12 & 3 \\
\hline & Zemun & 1981 & $22 / 6$ & $27 / 8$ & 94 & 94 & 0 & 6 \\
\hline & Osijek & 1979 & $6 / 6$ & $17 / 7$ & 18 & 100 & 0 & 0 \\
\hline & Osijek & 1981 & $22 / 6$ & $20 / 8$ & 70 & 97 & 0 & 3 \\
\hline
\end{tabular}

(1) Results of the cooperative program U.S.A.-P.R.C.

Résultats obtenus dans un programme en coopération entre les Etats-Unis d'Amérique et la République Populaire de Chine.

(2) Results of trapping by virgin females, $Z, Z \times E$ and $E$ (see text).

Résultats de piégeage par des femelles vierges de type $Z, Z \times E$ et $E$ (voir texte).

(3) For these additional results of a bilateral I.N.R.A.-Switzerland cooperation, the intermediate mixture is Z: E $50: 50$ instead of $35: 65$.

Dans ces résultats supplémentaires d'une coopération bilatérale I.N.R.A.-Suisse, le mélange intermédiaire est Z: E $50: 50$ au lieu de $35: 65$. 
to the same environmental stimuli but also on these precopulatory responses governed by the isomer blends of the pheromone.

Environmental (climatic and trophic) conditions might exert a selection pressure in favour of one particular phenotype. It is surprising to observe that conditions favouring the $E$ phenotype occur only in a restricted area in Europe (Northern Italy, Southern Switzerland) and in the north eastern states in USA (as a result of a population introduced from Italy). In the other observed locations, which are mainly in areas of intensive cultivation of corn, the environmental conditions favour the $\mathrm{Z}$ phenotype.

In a given place, variations from year to year in the responses of the males can be detected. A decrease of the total captures of $\mathrm{E}$ and $\mathrm{Z} \times \mathrm{E}$ phenotypes has been observed in recent years at Kobierzyce, Poland and Turda, Romania (Kobierzyce : $6 \%$ in 1973, $2 \%$ in 1974 and $0 \%$ in $1978,1979,1981$; Turda : $3 \%$ in $1973,7 \%$ in $1979,0 \%$ in $1980,1981)$. The same trend was also observed at Levesville, France ( $31 \%$ in $1974,26 \%$ in $1978,8 \%$ in 1979). These variations might be in correlation with variations in the environmental conditions selectively favouring one of the phenotypes. A striking example of these variations in the captures of males was observed in a locality of southwes- tern France (Z: E $97: 315,52,92 \%$; Z : E $35: 6529$, $18,6 \% ; Z: E \quad 3: 97,56,30,2 \%$ respectively during the years 1980, 1981, 1982) (STOCKEL \& DE LA MESSELIERE, 1983).

More advanced investigations, including the trapping of males, the study of their responses in the laboratory and the analysis of the secretion of the females, related to analysis of genetic distance (HARRISON \& VAWTER, 1977 ; CIANCHI $e t$ al., 1980), should be conducted in the different countries in order to test the hypotheses presented in this paper and to follow the variations in the frequencies of genes influencing the production of the different sex-pheromone components of the European corn borer.

Reçu le 14 juin 1983. Accepté le 20 septembre 1983.

\section{ACKNOWLEDGEMENTS}

The authors thank Ch. Brian (I.N.R.A., Bordeaux), for his advice in the field of genetics, Prof. H. C. Chiang (Univ. of Minnesota), and Dr. S. MAINI. (Univ. of Bologna) for their valuable criticism in reading the manuscript

\section{REFERENCES}

Anglade P., 1974. Emploi de phéromones sexuelles synthétiques pour l'attraction des mâles de la pyrale du maïs $O$. nubilalis $\mathrm{Hbn}$. Rev. Zool. Agric., 73, 37-46.

Anglade P., 1977. Variabilité des populations de la pyrale du maïs Ostrinia nubilalis $\mathrm{Hbn}$., d'après les piégeages par phéromones. Ann. Zool. Ecol. Anim., 9, 590.

Cardé R. T., Roelofs W. L., Harrison R. G., Vawter A. T., Brussard F. P., Mutuura A., Munroe E., 1978. European corn borer : pheromone polymorphism or sibling species?. Science, 199, 555-556.

Cianchi R., Maini S., Bullini L., 1980. Genetic distance between pheromone strains of the European corn borer, Ostrinia nubilalis : different contribution of variable substrate, regulatory and non regulatory enzymes. Heredity, 45, 383-388.

Harrison R. G. Vawter A. T., 1977. Allozyme differentiation between pheromone strains of the European corn borer, Ostrinia nubilalis. Ann. Entomol. Soc. Am., 70, 717-720.

Klun J. A., Chapman O. L., Mattes K. C., Wojtkowski P. W. Beroza M., Sonnet P. E., 1973. Insect sex pheromone : Minor amount of opposite geometrical isomer critical to attraction. Science, 181, 661-663.

Klun J. A. \& I.W.G.O. Cooperators, 1975. Insect sex pheromones : intraspecific pheromonal variability of Ostrinia nubilalis in North America and Europe. Environ. Entomol., 4, 891-894.

Klun J. A., Maini S., 1979. Genetic basis of an insect chemical communication system : the European corn borer. Environ. Entomol., 8, 423-426.

Klun J. A., Robinson J. F., 1971. European corn borer moth : sex attractant and sex attraction inhibitors. Ann. Entomol. Soc. Am., 64, 1083-1086.

Kochansky J. R., Cardé R. T., Liebherr J., Roelofs W. L., 1975. Sex pheromones of the European corn borer in New York. $J$. Chem. Ecol., 1, 225-231.
Maini S., Pallotti G., Platia G., 1978. Ostrinia nubilalis Hb. males trapping with virgin females of different genotypes in Bologna (Italy). In : « Les phéromones sexuelles des insectes et les médiateurs chimiques" 82-85. C.R. réunion Antibes, 1978. Publ. I.N.R.A.

Roelofs W. L., Cardé R. T., Bartell R. J., Tierney P. J., 1972. Sex attractant trapping of European corn borer in New York. Environ. Entomol., 1, 606-608.

Showers W. B., Reed G. L., Robinson J. F., Derozari M. B., 1976. Flight and sexual activity of the European corn borer. Environ. Entomol., 5, 1099-1104.

Stockel J., 1977. Mise au point d'un type de pic̀ge sexuel "I.N.R.A." pour insectes. In "Les Phéromones sexuelles des lépidoptères", 12-14. C.R. réunion Bordeaux, 1976. Publ. I.N.R.A., 217 p.

Stockel J., 1980. Influence de quelques facteurs conditionnant les captures de mâles d'Ostrinia nubilalis $\mathrm{Hb}$. (Lep. Pyralidae) au piège sexuel. In "Les phéromones sexuelles et les médiateurs chimiques chez les insectes. Utilisation en lutte intégrée », 97-104. C.R. réunion Colmar, 1980. Les Colloques de l'I.N.R.A., 3, 206 p.

Stockel J., 1981a. Relation entre la dose de phéromone synthétique et les captures de mâles d'Ostrinia nubilalis (Lép. Pyralidae) au piège sexuel. In: "Les médiateurs chimiques agissant sur le comportement des insectes ", 325-333, Symp. intern., Versailles, 1981. Les Colloques de l'I.N.R.A. 7, 414 p.

Stockel J., 1981 $b$. Comparaison des propriétés adhésives de cinq échantillons de glu en utilisation pour le piégeage sexuel des insectes. Déf. Vég., 207, 3-7.

Stockel J., de La Messelière C., 1983. Variations intraspécifiques de la pyrale du maïs, Ostrinia nubilalis $\mathrm{Hb}$. en France. Phytoma, 352, 41-42.

W.C.C.B.R.G. (Whole China Corn Borer Research Group), Chiang H. C., Klun J. A., Schwarz M., 1982. PRC-US Cooperative study on male response to synthetic Ostrinia pheromone in China. I.W.G.O. News, 3, 3-9. 